\title{
Investment and Economy Analysis of Water-Source Heat Pump System in Chongqing, China
}

\author{
Yong Ding, ${ }^{1,2}$ Xin Huang, ${ }^{1}$ Xiaobo Wu, ${ }^{1}$ and Baizhan $\mathrm{Li}^{1}$ \\ ${ }^{1}$ Key Laboratory of the Three Gorges Reservoir Region's Eco-Environment, Ministry of Education, Chongqing University, \\ Chongqing 400045, China \\ ${ }^{2}$ Faculty of Urban Construction and Environmental Engineering, Chongqing University, Chongqing 400045, China
}

Correspondence should be addressed to Yong Ding; dingyongqq@163.com

Received 17 October 2012; Revised 5 February 2013; Accepted 5 February 2013

Academic Editor: Abdurrahman Saydut

Copyright (C) 2013 Yong Ding et al. This is an open access article distributed under the Creative Commons Attribution License, which permits unrestricted use, distribution, and reproduction in any medium, provided the original work is properly cited.

\begin{abstract}
In China, the application of renewable energy witnesses rapid development. In the near future, a lot of demonstration projects will be built and thus it is urgent to know the economics of renewable energy building application technologies. Based on the renewable energy demonstration projects in Chongqing city, the author discussed the economy issue of water-source heat pump system (WSHPs) in order to provide suggestions for the application projects. According to the design information of demonstration projects, the average incremental investment, allowance, and payback period are calculated in this paper. Comparing WSHPs with traditional heating, ventilation, and air conditioning (HVAC) system, the saved energy of WSHPs is estimated in the current paper. The author calculated the amount of saved energy in unit applied area and unit intake water. Besides, the economy and efficiency of WSHPs project is analyzed at the end of this paper.
\end{abstract}

\section{Introduction}

China is an energy consumption power. The shortage of energy resources is a big problem. Nowadays, conventional energy resources cannot meet the current huge energy demand and thus it is urgent to apply renewable energy technologies to solve the problems of energy shortage. In China, about $1 / 3$ of total consumed energy is used in building, and HVAC systems account for more than 50\% building energy consumption [1]. Renewable energy building application is a significant way to alleviate the situation in China. Many demonstration projects have been completed and put into operation. The application of WSHPs, seawater heat pump system, and ground source heat pump system becomes a hot topics for researchers. Research is mainly about the application potential, energy efficiency rate, modeling, and performance evaluation [2-4]. In order to promote the application, it is worth studying whether WSHPs is economical or not in a city like Chongqing. Combined with the geological conditions and meteorological parameters, the condition of renewable energy sources as well as the energy saving potential and the energy saving rate [5-8] was analyzed. Tests of the demonstration projects were carried out in Chongqing. Researchers analyzed the economic benefits of the demonstration projects and studied the relationship between the natural source building application and indoor environment $[9,10]$.The available technologies for energy saving were discussed by various researchers and they suggested to create a database for the application of WSHPs [11]. Experiments were conducted and it was found that WSHPs projects in Chongqing should pay more attention to the grit removal of water. Besides, the factors which affect the performance of WSHPs, such as the type of water intake equipment [12, 13], were discussed. Based on a serial of experiments and research, databases of the Yangzi River and the Jialing River are created [14-16]. However, there are relatively few studies on the investment and economy analysis of demonstration projects in Chongqing. Based on eight WSHPs demonstration projects, the author obtains the average design energy efficiency ratio (EER), investment payback period, and saved energy amount by means of statistics and analysis, and also the appropriateness and economy of WSHPs were analyzed. 
TABLE 1: The average incremental investment and allowance of WSHPs project.

\begin{tabular}{|c|c|c|c|c|c|c|}
\hline & Building function & $\begin{array}{l}\text { Building area } \\
\left(10,000 \mathrm{~m}^{2}\right)\end{array}$ & $\begin{array}{l}\text { Incremental } \\
\text { investment } \\
\left(\mathrm{CNY} / \mathrm{m}^{2}\right)\end{array}$ & $\begin{array}{c}\text { Allowance } \\
(\mathrm{CNY} 10,000)\end{array}$ & $\begin{array}{c}\text { Average building area } \\
\text { allowance } \\
\left(\mathrm{CNY} / \mathrm{m}^{2}\right)^{*}\end{array}$ & $\begin{array}{c}\text { Payback period } \\
\text { (Year) }\end{array}$ \\
\hline 1 & Hotel & 2.6 & 195 & 119.92 & 46.12 & 12.4 \\
\hline 2 & Hotel & 1.18 & 247 & 108.96 & 92.34 & 9 \\
\hline 3 & Office & 5.4 & 95.07 & 468.48 & 86.76 & 12.4 \\
\hline 4 & Office & 3.8 & 166.14 & 279 & 73.42 & 15 \\
\hline 5 & Commercial and residential & 35 & 221.7 & 951 & 27.17 & 8.26 \\
\hline 6 & Commercial and residential & 7 & 76.9 & 468.56 & 66.94 & 18 \\
\hline 7 & Commercial and residential & 5.4 & 292.41 & 843 & 156.11 & 13.5 \\
\hline \multirow[t]{2}{*}{8} & Commercial and residential & 30 & 249.6 & 2272 & 75.73 & 7.29 \\
\hline & Average & & 193.01 & & 78.07 & 11.98 \\
\hline
\end{tabular}

* Some projects get allowance from Chongqing city government, while some get allowance from both Chongqing city government and the state. CNY is short for China Yuan.

\section{The WSHPs Application in Chongqing City}

Chongqing city (located at Western China, upper reaches of Yangzi River) belongs to typical hot summer and cold winter climate. The average temperature of Yangzi River and Jialing River is about $19-26^{\circ} \mathrm{C}$ in summer and $9-16^{\circ} \mathrm{C}$ in winter. Tests show that (1) both of the two rivers have an inconspicuous effect on vertical temperature stratification, (2) in addition to turbidity and sediment concentration, the water quality of two rivers can meet engineering requirements $[14,16]$. According to the standard ARI320 (standard of USA Air-conditioning and Refrigeration Institute), WSHPs is suitable and performs well in Chongqing. In addition, the hydrological environment of Chongqing provides extremely favorable conditions for the application of WSHPs as many buildings are distributed along Yangzi River and Jialing River.

\section{Demonstration Projects Analysis}

In Chongqing, pilot programs of WSHPs have been carried out since 2006. There are three projects including Yangzi River, Jialing River, and reservoir WSHPs. The three projects run well and then the first batch of renewable energy demonstration projects was organized in 2007 (six projects, $500,000 \mathrm{~m}^{2}$ building application in total). In 2008, the second batch of renewable energy demonstration projects was started. In 2009, Chongqing city successfully declared a national renewable energy demonstration city of China and needs to complete nearly 3.2 million $\mathrm{m}^{2}$ renewable energy applications. In recent years, more and more WSHPs demonstration projects have been invested. The author collected and sorted out data resources of those projects and got design information of eight WSHPs projects. Based on the information of those eight projects (including design system EER, investment payback period, energy savings, etc.), this paper presents an analysis of the operating efficiency, the increase investment, the investment payback period, and technological economy of WSHPs.
TABLE 2: The design system EER of traditional HVAC system.

\begin{tabular}{lccc}
\hline $\begin{array}{l}\text { Building } \\
\text { function }\end{array}$ & $\begin{array}{c}\text { Building } \\
\text { number }\end{array}$ & $\begin{array}{c}\text { Average design } \\
\text { system EER in } \\
\text { summer* }\end{array}$ & $\begin{array}{c}\text { Average design } \\
\text { system EER in } \\
\text { winter* }\end{array}$ \\
\hline Market & 26 & 2.9 & - \\
Hotel & 12 & 2.56 & 1.62 \\
Office & 122 & 2.71 & 1.58 \\
\hline \multicolumn{2}{c}{ Average } & 2.72 & 1.6 \\
\hline
\end{tabular}

*Water-cooled chillers in summer and boiler in winter

3.1. Incremental Investment. The water intake equipment and water treatment system are the essential components of WSHPs. Water intake equipment transport water into the host. And water treatment system improves water quality to meet the operation requirements of WSHPs. Due to the water intake equipment and water treatment system, the initial investment of WSHPs is higher than traditional HVAC system (water-cooled chillers in summer and boiler in winter). Thus, many countries including China use policy incentives to promote the development of heat pump system [17]. The incremental investment and the allowance of eight projects in Chongqing are shown in Table 1, respectively.

The average incremental investment of WSHPs is CNY $193.01 / \mathrm{m}^{2}$ and the average allowance is CNY $78.07 / \mathrm{m}^{2}$, which is about $40.5 \%$ of the average incremental investment. Without the allowance from government, the average payback period of WSHPs is about 11.98 years, while the average working life of the HVAC system is between 15 and 20 years. If allowance is considered, the average payback period declines to 7.13 years, a reasonable payback period. It is obviously that the payback period of WSHPs is too long to be wildly used without the support of the government.

3.2. Design System EER. Previous studies collected and sorted the system EER of traditional HVAC system of public building in Chongqing city $[18,19]$. The author analyzed and obtained the system EER data of the various public buildings (shown in Table 2). According to the design information 
TABLE 3: The design system EER of WSHPs.

\begin{tabular}{|c|c|c|c|c|c|}
\hline & Building function & $\begin{array}{l}\text { Rated cooling capacity } \\
(\mathrm{kw})\end{array}$ & $\begin{array}{c}\text { Average design system } \\
\text { EER in summer }\end{array}$ & $\begin{array}{c}\text { Average design } \\
\text { system EER in winter }\end{array}$ & $\begin{array}{c}\text { Actual } \\
\text { operational EER } \\
\end{array}$ \\
\hline 1 & Hotel & 1499 & 3.57 & 2.93 & - \\
\hline 2 & Hotel & 1362 & 4.11 & 3.17 & 3.4 in summer \\
\hline 3 & Office & 5856 & 3.26 & 3.13 & - \\
\hline 4 & Hospital & 3489 & 3.3 & 3.3 & $\begin{array}{l}2.9 \text { in summer } \\
\text { and } 3.1 \text { in winter }\end{array}$ \\
\hline 5 & Commercial and residential & 11887.5 & 4.13 & 3.62 & 3.6 in summer \\
\hline 6 & Commercial and residential & 3888.2 & 4.5 & 4.1 & - \\
\hline 7 & Commercial and residential & 10548 & 3.77 & 3.65 & 3.1 in summer \\
\hline 8 & Commercial and residential & 28400 & 4.15 & 3.29 & - \\
\hline \multicolumn{3}{|c|}{ Average } & 3.85 & 3.40 & \\
\hline
\end{tabular}

TABLE 4: The average design saved energy amount in unit applied area.

\begin{tabular}{|c|c|c|c|}
\hline & $\begin{array}{l}\text { Building area } \\
\left(10,000 \mathrm{~m}^{2}\right)\end{array}$ & $\begin{array}{c}\text { Design amount } \\
\text { of saved energy } \\
\text { (Tce } / \text { year) }\end{array}$ & $\begin{array}{c}\text { Amount of saved energy } \\
\text { in unit applied area } \\
\left(\text { Tce } / 10,000 \mathrm{~m}^{2}\right)\end{array}$ \\
\hline 1 & 2.6 & 307 & 118.08 \\
\hline 2 & 1.18 & 141.6 & 120 \\
\hline 3 & 5.4 & 189.6 & 35.11 \\
\hline 4 & 3.8 & 160 & 42.11 \\
\hline 5 & 35 & 1234.22 & 35.26 \\
\hline 6 & 7 & 315.23 & 45.03 \\
\hline 7 & 5.4 & 777.9 & 114.06 \\
\hline 8 & 30 & 8550 & 285 \\
\hline \multicolumn{3}{|c|}{ Average } & 99.33 \\
\hline
\end{tabular}

${ }^{*}$ Tce is short for Ton of standard Coal Equivalent.

of eight WSHPs projects, the design system EER of watersource heat pump is calculated and the result is shown in Table 3. Furthermore, the author got the actual operational EER of some projects by energy efficiency test, as shown in Table 3.

In Chongqing, the average design system EER of traditional HVAC system is 2.72 in summer and 1.6 in winter (shown in Table 2), while the average design system EER of heat pump system is 3.85 in summer and 3.40 in winter (shown in Table 3), a rise of $41.54 \%$ and $112.5 \%$, respectively. It is obvious that the performance of WSHPs is more efficient than traditional HVAC system in Chongqing. Therefore, the operation cost of WSHPs is lower than that of traditional HVAC system.

3.3. Saved Energy Amount. According to the design information of the eight WSHPs projects, the author calculated the average amount of saved energy in unit applied area and in unit quantity of water, shown in Tables 4 and 5 , respectively. The saved energy amount of WSHPs project is calculated on the basis of the energy consumption of traditional HVAC system. The energy consumption of traditional HVAC system is obtained from the database, and the database comes from the survey of large public buildings in Chongqing.

The average design saved energy amount in unit applied area is 99.33 Tce per $10,000 \mathrm{~m}^{2}$ per year and the average design saved energy amount in unit water is $2.656 \times 10^{-4} \mathrm{Tce} / \mathrm{m}^{3}$. The two parameters may provide valuable reference to the investment analysis and predict the saved energy amount of WSHPs project in Chongqing.

3.4. Economy and Efficiency. According to the above statement, if the government invests CNY 50 million to support WSHPs, projects may achieve great economic and environmental benefits (as shown in Table 6). Under the premise that the electricity price is CNY 0.828 per Kwh in Chongqing, and the power conversion is calculated by $1 \mathrm{Kwh}=0.404 \times 10^{-3}$ Tce (according to the data of national bureau of Statistics). 1 Tce can produce 2.77 tons of $\mathrm{CO}_{2}$, according to the data of National Scheme to Facing Climate Change. Based on those parameters, the economic and environmental benefit of every CNY 50 million invested by the government is estimated in Table 6. The cost escalation in electricity cost is not considered in Table 6.

As the average building area allowance is CNY $78.07 / \mathrm{m}^{2}$, the demonstration area of WSHPs projects will be 0.6405 million $\mathrm{m}^{2}$ if CNY 50 million is invested. These projects will possibly save 6362.09 Tce, a reduction of 14486.48 tons of $\mathrm{CO}_{2}$ emissions and save 15.7478 million $\mathrm{Kw}$ energy consumption per year. CNY 50 million invested to support heat pump system projects makes a significant contribution to environmental protection. Also, these projects can relieve the increasing pressure on the power grid and reduce the investment in electric power plants. The economy and efficiency of WSHPs is remarkable.

\section{Conclusion}

(1) WSHPs can hardly be popularized without the support of the government as the initial investment is too high at present in China. The design system EER 
TABLE 5: The average design saved energy amount in unit intake water.

\begin{tabular}{ccccc}
\hline & $\begin{array}{c}\text { Water intake amount } \\
\left(\mathrm{m}^{3} / \mathrm{h}\right)\end{array}$ & $\begin{array}{c}\text { Design amount of saved energy } \\
\text { (Tce/year) }\end{array}$ & $\begin{array}{c}\text { Design performance period of } \\
\text { HVAC system per year } \\
(\mathrm{h})\end{array}$ & $\begin{array}{c}\text { Amount of saved energy } \\
\text { in unit water } \\
\left(\text { Tce } / \mathrm{m}^{3}\right)\end{array}$ \\
\hline 1 & 328.3 & 307 & 2400 & $3.896 \times 10^{-4}$ \\
2 & 489 & 141.6 & 2400 & $1.21 \times 10^{-4}$ \\
3 & 1200 & 189.6 & 2400 & $6.58 \times 10^{-5}$ \\
4 & 750 & 160 & 1600 & $1.333 \times 10^{-4}$ \\
5 & 5600 & 1234.22 & 3048 & $7.23 \times 10^{-5}$ \\
6 & 439 & 315.23 & 1600 & $4.488 \times 10^{-4}$ \\
7 & 1908 & 777.9 & 2400 & $1.699 \times 10^{-4}$ \\
8 & 3235 & 8550 & 3650 & $7.241 \times 10^{-4}$ \\
\hline \multicolumn{7}{c}{} \\
\hline
\end{tabular}

TABle 6: The economic and environmental benefit of every 50 million.

\begin{tabular}{lc}
\hline & Value \\
\hline Invested money & $50,000,000(\mathrm{CNY})$ \\
Average building area allowance & $78.07\left(\mathrm{CNY} / \mathrm{m}^{2}\right)$ \\
Demonstration area & $64.05\left(10,000 \mathrm{~m}^{2}\right)$ \\
Coal saving amount per year & $6362.09(\mathrm{Tce})$ \\
Electricity saving amount per year & $1574.78(10,000 \mathrm{Kwh})$ \\
Reducing $\mathrm{CO}_{2}$ emission per year & 14486.48 (Tons) \\
\hline
\end{tabular}

of WSHPs is 3.85 in summer and 3.40 in winter, a rise of $41.54 \%$ and $112.5 \%$ form those of traditional HVAC system, respectively. However, the incremental investment is up to CNY $193.01 / \mathrm{m}^{2}$. It is estimated that the payback period will be nearly 12 years without allowance. The average allowance is CNY $78.07 / \mathrm{m}^{2}$, nearly $40.5 \%$ of incremental investment, so if the allowance of government is considered, the payback period of WSHPs project will be declined to nearly 7 years.

(2) The economy and efficiency of WSHPs is remarkable. According to the above estimation, if CNY 50 million is invested to support WSHPs applications, these projects will bring great benefits. One-off subsidy will possibly reduce the consumption of Tce and achieve a reduction of $\mathrm{CO}_{2}$ emission, so it will contribute to reduce greenhouse emissions and protect the environment.

\section{Acknowledgments}

The authors would like to thank the Chongqing Municipal Commission of Urban-Rural Development for providing project material and technical support for this study. The paper received Project (2010DFA72740-03, 2010DFA7274006-06) support from US-China Clean Energy Research Center.

\section{References}

[1] R. Yao, B. Li, and K. Steemers, "Energy policy and standard for built environment in China," Renewable Energy, vol. 30, no. 13, pp. 1973-1988, 2005.

[2] L. Zhen, D. M. Lin, H. W. Shu, S. Jiang, and Y. X. Zhu, "District cooling and heating with seawater as heat source and sink in Dalian, China," Renewable Energy, vol. 32, no. 15, pp. 2603-2616, 2007.

[3] Y. Cho and R. Yun, "A raw water source heat pump airconditioning system," Energy and Building, vol. 43, no. 11, pp. 3068-3073, 2011.

[4] J. Liang, Q. Yang, L. Liu et al., "Modeling and performance evaluation of shallow ground water heat pumps in Beijing plain, China," Energy and Buildings, vol. 43, no. 11, pp. 3131-3138, 2011.

[5] L. Zhang, B. Li, and Y. Ding, "Studying on the applications of natural resource in Chongqing," Building Energy \& Environment, vol. 28, no. 6, pp. 42-45, 2009.

[6] Y. Ding, Y. Jia, B. Li, and A. Montshiwa, "Analysis of integrated efficiency for surface water heat pump system," in Proceedings of the 11th World Renewable Energy Congress, Abu Dhabi, United Arab Emirates, September 2010.

[7] Y. Ding, B. Li, S. Jinlong et al., "The analysis of shallow water for the application of water-source heat pump system in Chongqing," in Proceedings of the Annual Meeting of Heating Ventilating \& Air Conditioning in China, 2008.

[8] Z.-Y. Wang, X.-Z. Fu, Y. Wang et al., "Analysis of Yangtze River water as a potential source for developing a water source heat pump in Chongqing," Journal of Chongqing Jianzhu University, vol. 30, no. 1, pp. 92-95, 2008.

[9] Y. Ding, B. Li, Q. Luo et al., "Effect of natural resource on improving indoor thermal environment in Chongqing," Journal of Chongqing University, vol. 30, no. 9, pp. 127-133, 2007.

[10] Y. Ding, B. Li, Q. Luo, H. Liu, and M. Liu, "Effect of natural resource on improving indoor thermal environment in Chongqing," Frontiers of Architecture and Civil Engineering in China, vol. 3, no. 2, pp. 211-218, 2009.

[11] Y. Rongliang, J. Wenchao, Y. Ding et al., "The available technologies for building energy saving in Chongqing," Building Application of Renewable Energy, vol. 16, pp. 24-25, 2009.

[12] J.-H. Chen, M. Liu, S.-X. Wu, Y. Liu, Y. Fan, and D.-X. Lai, "Performance analysis of water-intaking mode for lakesource heat pump air-conditioning system," Journal of Hunan University, vol. 36, no. 2, pp. 79-83, 2009. 
[13] Y. Ding, Y.-Y Su, B. Li et al., "The basic parameters obtained for design of ground source heat pump," in Proceedings of the International Conference on E-Product E-Service and EEntertainment (ICEEE '10), pp. 1-6, November 2010.

[14] B. Li, J. Zunfeng, Y. Ding et al., "Basic database for applications of river source heat pump in Chongqing," Heating Ventilating and Air Conditioning, vol. 41, no. 1, pp. 95-98, 2011.

[15] J. Zunfeng, Y. Ding, Y. Jia et al., "Analysis of river water quality in the application of river source heat pump system," Journal of Water Resources \& Water Engineering, vol. 21, no. 6, pp. 53-56, 2010.

[16] Y. Ding and J. Zunfeng, "Analysis of river water temperature in the application of water-source heat pump system," Water \& Waste Water Engineering, vol. 36, no. 9, pp. 166-170, 2010.

[17] C. R. Lloyd and A. S. D. Kerr, "Performance of commercially available solar and heat pump water heaters," Energy Policy, vol. 36, no. 10, pp. 3807-3813, 2008.

[18] Y. Xiaoping, F. Xiangzhao, X. Yimin, and L. Zhenguo, HVAC system design EER analysis of office, market, hotel building in Chongqing, Chongqing University, 2006.

[19] B. Li, Y. Zhang, Y. Ding, and Y. Tan, "Status analysis of public energy management in Chongqing," Heating Ventilating \& Air Conditioning, vol. 40, no. 9, pp. 112-117, 2010. 


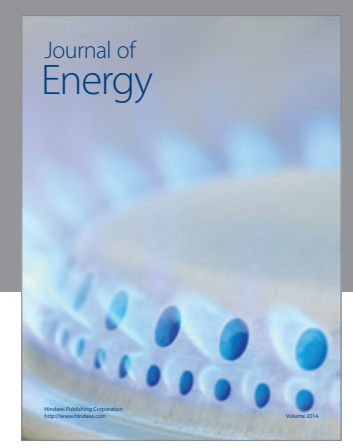

Journal of

Industrial Engineering
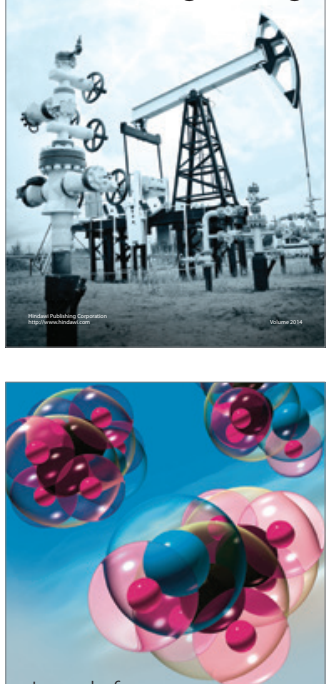

Fuels
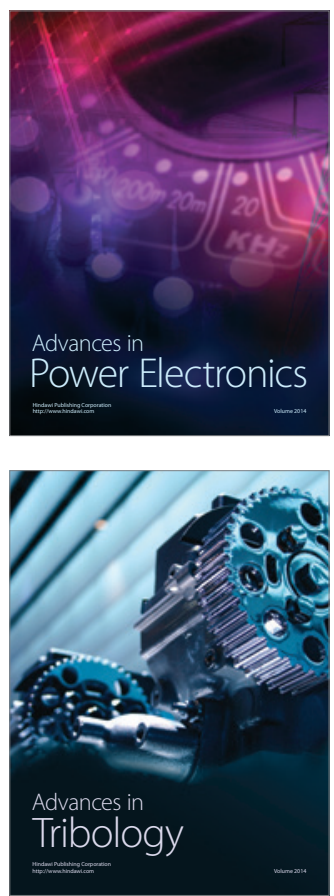

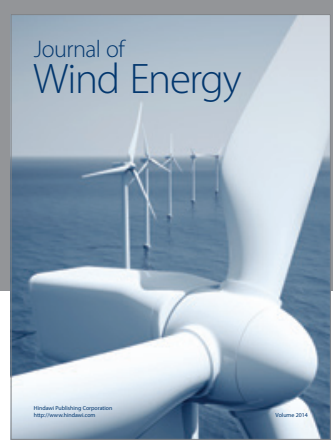

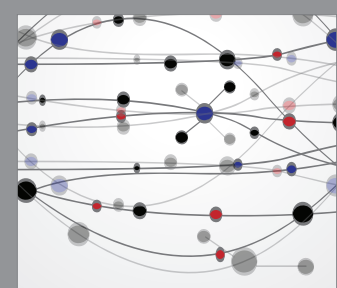

The Scientific World Journal

Submit your manuscripts at http://www.hindawi.com

Journal of

Structures
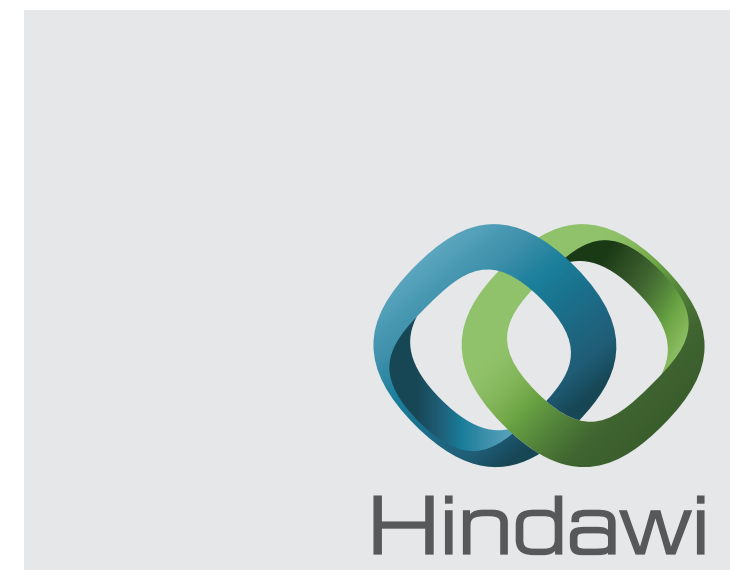

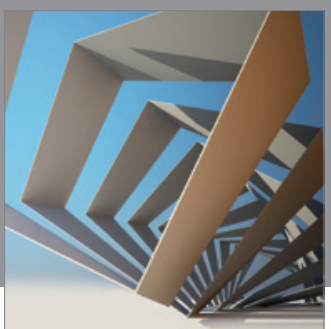

Rotating

Machinery
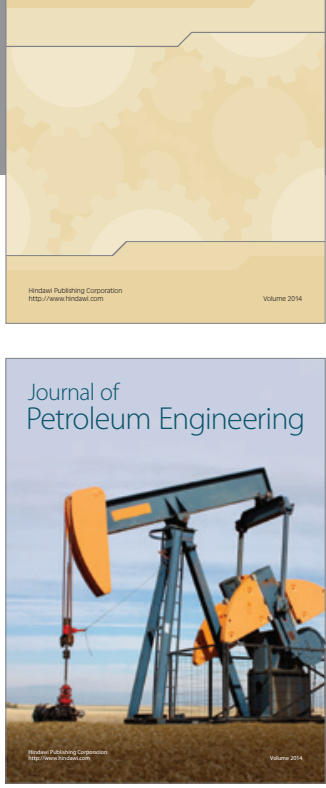

Journal of

Solar Energy
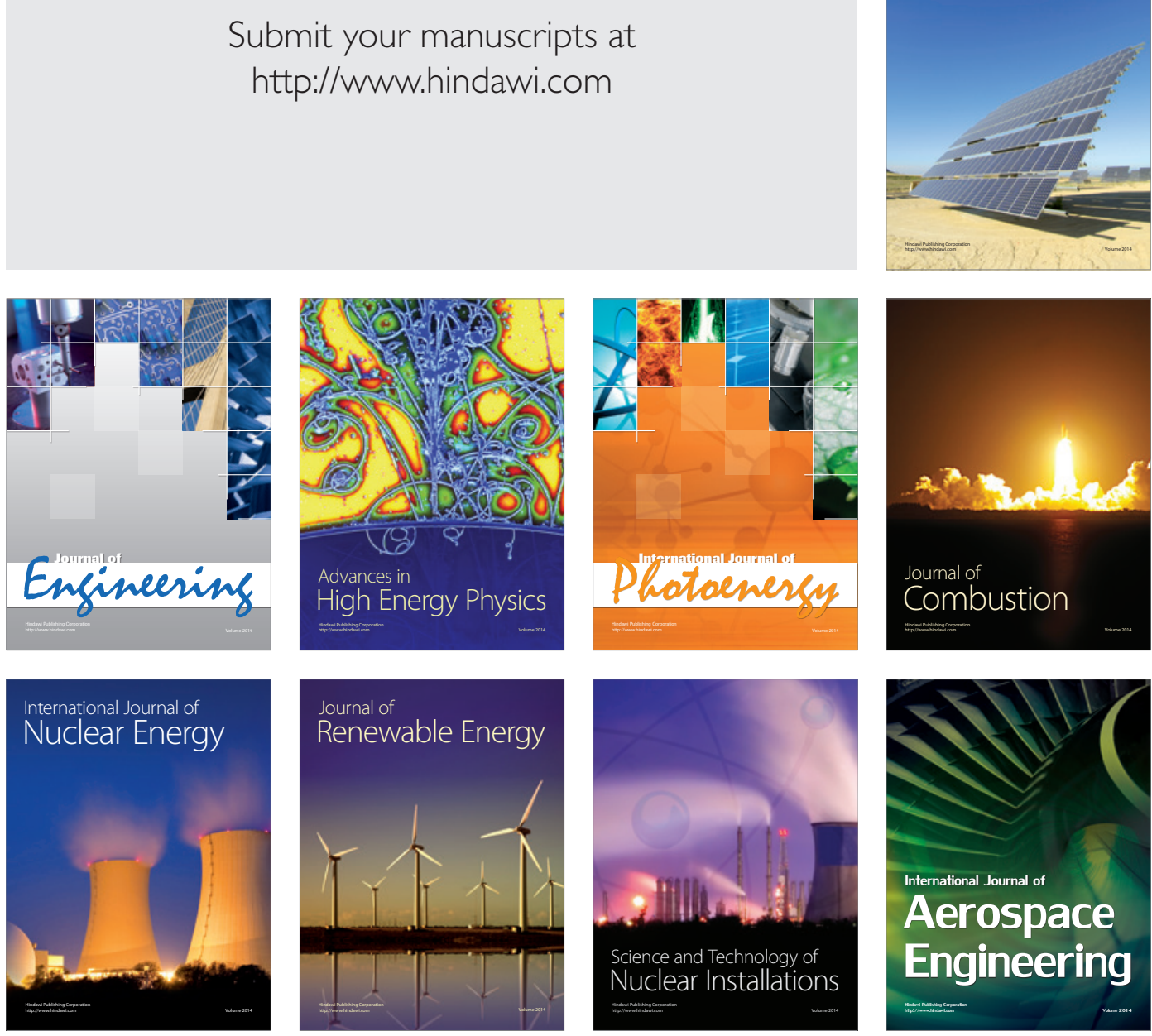